\title{
IDENTIFIKASI MASALAH KESEHATAN PENDUDUK RUKUN WILAYAH 01 KELURAHAN ABEPANTAI ABEPURA KOTA JAYAPURA
}

\section{(IDENTIFY HEALTH PROBLEM OF POPULATION RUKUN WILAYAH 01 SUB DISTRIC ABEPANTAI ABEPURA JAYAPURA CITY)}

\author{
Fransisca B. Batticaca ${ }^{1 *}$, Imma Wardhani ${ }^{2}$ \\ ${ }^{1,2}$ Dosen Program Sudi Ilmu Keperawatan Fakultas Kedokteran Uiversitas Cenderawasih \\ J1. Raya Sentani Abepura Jayapura Papua (99351) \\ *e-mail: sis_ppnu@yahoo.com
}

\begin{abstract}
ABSTRAK
Tujuan penelitian untuk mengidentifikasi masalah kesehatan penduduk di RW 01 Kelurahan Abepatai Abepura Kota Jayapura. Desain penelitian descriptive cross sectional melalui survey. Sampel sebanyak 54 kepala keluarga diukur menggunakan kuesioner yang diadopsi dari panduan parkatek profesi stase keperawatan komunitas Ners Fakultas Kedokteran Universitas Cenderawasih untuk mengidentifikasi karakteristik penduduk; data karakteritik rumah, dan kebersihan lingkungan; air bersih dan jamban, penyakit yang pernah dialami dalam satu tahun terakhir, pelayanan kesehatan balita, dan pelayanan keluarga berencana. Dilaksanakan pada bulan Agustus 2014 sampai dengan Agustus 2015. Analisis statistic menggunakan program SPSS dengan computer. Dari 54 Kepala keluarga teridentifikasi penduduk sering terinfeksi penyakit Tuberkulosis 35\%, Infeksi Saluran Pernafasan Akut 31,5\%, Dermatitis, Malaria, and Rheumatoid 9.3\%, DBD and Diarrhea 5.6\%; tinggal di rumah semi permanent $20.4 \%$, lantai tanah $27,8 \%$, tidak ada ventilation $75.1 \%$, lingkungan kotor $63 \%$, membuang sampah ke suangai 54.5\%; sumber air dari mata air 100\%; vector berbahaya nyamuk $38 \%$; toileting di WC umum 42,6\%; buang limbah di sembarang tempat 51,5\%, menimbang anak secara teratur $58,1 \%$, memiliki KMS 51,25\%, iminsiasai lengkap 41,9\%, mendapatkan MP-ASI 89,4\%; tidak ikut KB 72.2\%. Sumber imformasi kesehatan dari puskesmas/Posyandu 46,3\%; pelayanan kesehatan di RS $74,1 \%$. Kemudian merumuskan masalah keperawatan menggunakan Nanda meliputi risiko tinggi infeksi saluran pernafasan akut, diare, ketidakefektifan penatalaksanaan kesehatan komunitas, ketidakefektifan penatalaksanaan kesehatan balita. Kesimpulan penelitian bahwa status kesehatan penduduk RW 01 Abepantai berada pada level rendah. Sarannya yaitu meningkatan status kesehatan penduduk melalui akses pelayanan, membangun kembali lingkungan perumahan melalui kemitraan antara Dinas Kesehatan, Departemen Pekerjaan Umum, Pihak Swasta, dan Perguruan Tinggi .

Kata kunci: Abepantai, Masalah Kesehatan, Kelurahan, Penduduk
\end{abstract}

\section{ABSTRACT}

The aim $f$ this study was to identify health problem of people Rukun Wilayah 01 Sub Distrc Abepantai Abepura Jayapura city. Research design was descriptive cross sectional approach trought out survey. Pololation consisted of 54 household used questioner which adopted from proffesinal nursing practice at community level Ners Faculty of Medicine University of Cenderwasih to identify people caractirize, household characterize, and environment hygiene, clean water and latrine,, the desiases that infected people in one year, under five years old of childrens' services, and family pnanninf sevices.. Research was conducted August 2014 to August 2015. Statistical analyzed found most of people always infected 
Tuberculosis 35\%, Acute Upper Tract Infection 31.5\%, Dermatitis, Malaria, and Rheumatoid 9.3\%, DHV and Diarrhea 5.6\%; live in semi permanent house $20.4 \%$, land floor $27.8 \%$, no has ventilation $75.1 \%$, dirty environment $63 \%$, put rubbish on the river $54.5 \%$; sours of water from spring $100 \%$, danger vector mosquito $38 \%$; toileting at general water close 42,6\%; put waste in any places $51.5 \%$, weighted child regularly 58.1\%, has identity healthy card $51.25 \%$, completely immunization $41.9 \%$, artificial breast feeding $89.4 \%$, absent of family planning $72.2 \%$. Source of information at public health center/integrated heath post $46.3 \%$, health care services at the hospital $74.1 \%$. Nursing problem of community RW 01 consisted of: High risk upper tract infections, diarrhea; Ineffective community health management; Ineffective health management of children under five years old. Health status of people at low level. Its needed to improve health status of people by access health services, rebuild houses environment through partnership between Health Department, General Worker Department, Private sector, and University institution.

Key word: Abepantai, Health problem, Pupulation, Subdistric

\section{PENDAHULUAN}

Kelurahan Abepantai merupakan wilayah kerja Puskesmas Abepantai, terletak di Kecamatan Abepura Kota Jayapura Povinsi Papua. Kelurahan Abepantai terbentuk berdasarkan Peraturan Daerah Kota Jayapura Nomor 9 Tahun 2006, merupakan pemekaran dari Kelurahan Asano. Pemerintah Kelurahan Abepantai mulai pada tanggal 06 Feruari 2007 yang dipimpin oleh John, A.Awi, S.Sos. Penduduknya merupakan bagian dari pelayanan kesehatan Puskesmas Abepantai termasuk Rw 01 RW 01 dimana $100 \%$ penduduknya merupakan etnis asli Papua yang berasal dari wilayah Memberamo Tengah. Selain itu Puskemas Abepantai juga melaksanakan program perawatan kesehatan masyarakat. Data tersebut menujukkan bahwa RW 01 rentan dan risiko terhadap mengalami masalah kesehatan.

Perawatan kesehatan masyarakat (Perkesmas) adalah pelayanan keperawatan professional yang merupakan perpaduan antara konsep kesehatan masyarakat dan konsep keperawatan yang ditujukan pada seluruh masyarakat dengan penekanan pada kelompok risiko tinggi. Dalam upaya pencapaian derajad kesehatan yang optimal dilakukan melalui peningkatan kesehatan (promotif) dan pencegahan penyakit (peventif) disemua tingkat pencegahan (level of prevention) dengan menjamin keterjangkauan pelayanan kesehatan yang dibutuhkan dan melibatkan klien sebagai mitra kerja dalam perencanaan, pelaksanaan, dan evealuasi pelayanan keperawatan (Depkes, 2006).

Masalah kesehatan individu, keluarga, kelompok, dan masyarakat dapat dideteksi melalui asuhan keperawatan. Asuhan keperawatan adalah suatu proses sistemik, rasional, menggunakan metode perencanaan dan pemberian asuhan perawatan individu. Tujuan asuhan keperawaan adalah untuk mengidentifikasi masalah atau kebutuhan kesehatan aktual atau potensial untuk mengidentifikasi kebutuhan klien. Klien mencakup individu, keluarga, kelompok atau komunitas. Terdapat enam tahapan proses keperawatan yaitu: pengkajian, diagnosis, identifikasi tujuan, perencanaan, dan evaluasi. Identifikasi dilaksanakan pada level pertama melalui pengkajian. Pengkajian adalah pengumpulan, pengorganisasian, validasi, dan dokumentasi data secara sistematis. Pada kenyataan pengkajian adalah suatu proses secara kontinyu dilaksanakan selama seluruh tahap proses keperawatan (Kozier \& Erb's, 2012). Kuesioner yang digunakan mengumpulkan data terdiri dari kuesioner data karakteristik penduduk; data karakteritik rumah, dan kebersihan lingkungan; air bersih dan jamban, penyakit yang pernah dialami dalam satu tahun terakhir, pelayanan kesehatan balita, dan 
peningkatan kasus dibanding tahun 2012 kasus

pelayanan keluarga berencana bersumber dari bukua panduan praktek profesi keperawatan komunitas Program Studi Ilmu keperawatan Fakultas Kedokteran Uncen Universitas Cenderawasih (2014).

Pada tahun 2013 teridentifkasi 10 besar penyakit di wilayah Kota Jayapura yaitu ISPA sebagai peringkat pertama $75,179 \%$, Penyakit Kulit, 19,61\%, Penyakit Rongga Mulut 15,891\%, Malaria, 15,541 Penyakit Sistem Otot dan Jaringan Pengikat, 14,375\%, Gastritis 7,886\%, Diare 7,165\%, Hipertensi 4,483\%, Kecelakaan/Ruda Pakasa, 4,436\%, Penyakit lainnya, 37,003\%. Disamping 10 penyakit terebar tersebut juga teridentifikasi kasus lain seperti Kasus Diara pada Balita 23\% mengalami penurunnan dibandingkan tahun 2012 sebesar 42,3\% Dislaporkan juga kasus lepra di 12 Puskesmas yang berada di Kota Jayapura 415 oran, 12 orang diantaranya di Puskesmas Abepantai; kasus HIV dilaporkan sebanyak 431 penderita dan AIDS sebanyak 3438 penderita. Sebagian besar kasus terjadi pada populasi umum. Sementara penderita Infeksi Menular Seksual (IMS) berjumlah 2584 kasus dan $100 \%$ ditangani; Cakupan penemuan penderita TB Paru BTA (+) baru tahun 2013 adalah sebanyak 621 kasus, kasus ini meningkat dibanding tahun 2012 yaitu 437 kasus. Sementara BTA (+) yang diobati sebanyak 621 kasus. Untuk kasus TB Paru kambuh ditemukan sebanyak 44 kasus pada tahun 2013, kasus ini tetap dibanding tahun 2012 sebanyak 44 kasus juga. Adapun CDR TB Paru pada tahun 2013 ini adalah $104 \%$ dengan SR 40\% (sampai triwulan I tahun 2013); Penemuan kasus Pneumonia pada semua kelompok umur pada tahun 2013 sebanyak 185 pasien, dimana 50\% diantaranya adalah balita. Penemuan kasus Pnemonia Balita di Puskesmas pada tahun 2013 sebanyak 101 pasien dan $100 \%$ dapat ditangani. Sementara data dari Rumah sakit tidak didapat. Jika dibandingkan dengan tahun 2012 sebanyak 39 pasien, terjadi peningkatan kasus; DBD sebanyak 139 penderita tanpa kematian, terjadi
DBD sebanyak 72 kasus dengan kematian 4 orang (Dinkes Kota Jayapura, 2013).

Hasil studi pendahuluan di Puskesmas Abepanai bulan. Agustus 2014 teridentifikasi 10 penyakit utama, yaitu: Infeksi Saluran Pernapasan Akut (ISPA) $40 \%$ leih tinggi dari angka nasional $25 \%$, papua $31,2 \%$; diikuti oleh penyakit lain 19,5\%; Mialgia 10,\%, Diare $7,4 \%$ seikit lebih tinggi dari prevalensi nasional $3,5 \% \quad 6.2 \%$, Dermatitis $4,7 \%$, conjunctivitis 4.4\%; Malaria tertiana 27\%; Farisela 2. \%; Caries 2,1\% ; Malaria lebih tinggi dari angkdan a nasional 1,9\%, Papua: Insidensi 9,8\% dan prevalensi 28,6 \%(Riskesdas, 2013).Semntara menurut peugas penduduk di RW 01 memilki berbaai masalah kesehatan, diantaranya diare, malaria, dan ISPA, dan TBC, warga juga jarang berobat ke Puskesmas dan membawa anak ke posynadu karena jarang berada di rumh, tetapi lebih banya waktunya digunakan berkebun. Hasil observasi Nampak rumah kumuh, bebeapa ank Nampak pilek, tidak emngguakan sandal ketika sedang bermain., infomrasi lain didapatkan penduduk RW 01 cendereung mengkonsumsi minuman berlakohol. Berbagai upaya telah dilakukan pemerintah diantaanya perebaikan pemukiman penduduk melalui program kota tanpa kumuh (Kotaku), perawatan ksehatan masyarakat (Perkesmas), peromosi kesehatan olah petugas puskesmas, namun masih ditemukan masalah kesehatan masyarakat di wihlayah RW 01. Sehingga perlu diterapkan asuhan keperawatan masyarakat di RW 01 Kelurahan Abepantai Abepura Kota Jayapura.

Bedasarkan hal tersebut dapat dirumuskan hipotesisi penelitaian bahwa ada masalah kesehatan penduduk RW 01 Kelurahan Abapantai Abepaura Kota Jayapura. Tujuan pnelitian mengidentifikasi masalah kesehatan penduduk RW 01 Kelurahan Abapantai Abepaura Kota Jayapura mencakup karakteristik rumah dan kebersihan lingkungan, sarana air bersih dan jamban; penyakit yang sering dilami penduduk, sumber informasi dan tempat 
jamban; penyakit yang sering dilami

pelayanan kesehatan, pelayanan kesehatan balita, dan pelayanan keluarga berencana.

\section{METODE}

Desain penelitian descriptive cross sectional melalui survey. Samplenya sebanyak 54 kepela keluarga menggunakan purposive sampling. Alat ukur yang menggunakan kuesioner yang diadopsi dari panduan parkatek profesi stase keperawatan komunitas Ners Fakultas Kedokteran Universitas Cenderawasih untuk mengetahua karakteristik penduduk; data karakteritik rumah, dan kebersihan lingkungan; air bersih dan jamban, penyakit yang pernah dialami dalam satu tahun terakhir, pelayanan kesehatan balita, dan pelayanan keluarga berencana. Pengumpulan data dilaksanakan setelah peneliti mendapat iin dari Dinas Keshaan Kota. Data yang dikumpulkan terdiri dari data sekunder tentang profil puskesmas dan data Jumlah kepala keluarga diperoleh dari ketua RW dan ketua rukun tetanga (RT) setempat. Penelitian ini menggunakan mahasiswa praktek Profesi sebagai pengumpul data sehingga sebelum dilakukan pengumpulan data dilakukan persamaan persepsi dengan melatih masahasiswa mengisi kuesioner sebelum melaksanakan penelitian dengan cara survey untuk mendapatkan data primer dimana setiap mahasiswa mendatangi rumah penduduk didampingi aparat setempat untuk mendapatkan data primer. Sedangkan data sekunder diperoleh dari data Profil Puskesmas Abepantai, Kelurahan Abepantai dan Ketua RA 01 Abepantai. Populasi seluruh rumah tangga 54 kepala keluarga (KK) di RW 01. Sampel adalah seluruh rumah tangga 54 dan anggotanya di RW 01.

Instrumen penelitian yang digunakan terdiri dari demografi keluarga berisi tentang karakteristik penduduk mencakup usia, jenis kelamin, pendidikan, pekerjaan, agama, etnis, pendapatan; karakteristik rumah dan kebersihan lingkungan, sarana air bersih dan penduduk, sumber informasi dan tempat pelayanan kesehatan, pelayanan kesehatan balita, dan pelayanan keluarga berencana. Pengumpulan data dengan cara interview dan observasi menggunakan kueseier yang telah disiapkan. Seluruh data diperoleh berdasarlan laporan responden, dan observasi. Pengolahan data dengan cara univariate menggunakan program SPSS dengan computer.

Untuk melindungi hak asasi manusia, penelitian ini mendapatkan ijin dari Dinas Kesehatan Kota Jayapura. Kepala Puskesmas, Kepala Kelurahan, Ketua RW 01 serta tokoh agama bersama diberi informasi penjelasan mengenai tujuan serta prosedur, dan manfaat penelitian. Keluarga yang berpartisipasi pada penelitian ini menandatangani surat persetujuan (Inform consent). Bila ditemukan ada anggota keluarga yang mengalami masalah gangguan kesehatan dirujuk ke Puskesmas atas persetujuan ketua aparat setempat.

\section{HASIL}

\section{Karakteristik Penduduk}

Table 1. Distribusi Frekuensi Karakteristik Penduduk

\begin{tabular}{lcc}
\hline \multicolumn{1}{c}{ Karakteristik } & n & \% \\
\hline Usia dalam tahun & & \\
$\quad 0-5$ & 19 & 8,2 \\
$6-12$ & 35 & 15 \\
$13-18$ & 24 & 10,3 \\
$19-35$ & 44 & 18,9 \\
$36-54$ & 83 & 35,6 \\
$>55$ & 28 & 12 \\
Jenis Kelamin & & \\
Laki-laki & 117 & 50,2 \\
Perempuan & 116 & 49,8 \\
Etnis & & \\
Papua & 233 & 100 \\
Agama & & \\
$\quad$ Cristian Protestant & 233 & 100 \\
Pekerjaan & & \\
Tani & 92 & 67,2 \\
\hline
\end{tabular}




\begin{tabular}{lcc}
\hline Tidak bekerja & 26 & 19,0 \\
PNS & 18 & 13,1 \\
Swasta & 1 & 0,7 \\
TNI/Polri & 0 & 0 \\
Pendidikan & & \\
Tidak sekolah & 63 & 31,8 \\
Taman-kanak-kanak & 3 & 1,5 \\
Sekolah Dasar & 59 & 29,8 \\
SMP & 14 & 7,1 \\
SMA & 48 & 24,2 \\
Ademik/Diploma & 11 & 5,6 \\
Pendapatan (Rp) & & \\
<500.000 & 37 & 68,6 \\
500.000-1.000.000 & 13 & 24,0 \\
> 1.000.000 & 4 & 7,4 \\
\hline
\end{tabular}

Tabel 1 menunjukkan mayoritas penduduk RW 0I Kelurahan Abepantai berada pada rentang usia produktif. Untuk kelompok usia 26-50 tahun 35,6\%, laki-laki 50,2\%, petani $67,2 \%$, tidak sekolah $31,8 \%$, Etnis Papua: Mambramo Tengah 100\%, Kristen Protestan $100 \%$, penghasilan perbulan Rp.< $500.00068,6 \%$ dari total penduduk 233 jiwa.

Karakteritik Rumah, dan Kebersihan Lingkungan

Tabel 2. Distribusi Frekuensi Karakteritik Rumah

\begin{tabular}{lcc}
\hline Karakeristik & n & \% \\
\hline $\begin{array}{l}\text { Kepemilikan Rumah } \\
\quad \text { Milik Pribadi }\end{array}$ & 54 & 100 \\
Tipe Rumah & & \\
$\quad$ Non Permanen & 26 & 48,1 \\
$\quad$ Permanen & 11 & 20,4 \\
$\quad$ Semi Permanen & 17 & 31,4 \\
Jenis Lantai & & \\
$\quad$ Papan & 33 & 61,1 \\
$\quad$ Plester & 6 & 11,1 \\
$\quad$ Tanah & 15 & 27,8 \\
Ventilasi Rumah & & \\
$\quad$ Ada & 13 & 61,1 \\
$\quad$ Tidak Ada & 41 & 75,9 \\
\hline
\end{tabular}

Tabel 2,3 menunjukkan $100 \%$ penduduk memiliki rumah pribadi, $48,1 \%$ memiliki tipe rumah non permanen, jenis lantai papan $61,1 \%$, tanah $27,8 \%$, berventilasi $75,9 \%$.

Tabel 3.Distribusu Frekuensi Kebersihan Lingkungan

\begin{tabular}{lcc}
\hline Karakeristik & n & \% \\
\hline Kebersihan & & \\
Lingkungan & & \\
$\quad$ Besih & 20 & 37,0 \\
$\quad$ Tidak Bersih & 34 & 63,0 \\
$\quad \begin{array}{l}\text { Tempat Pembuangan } \\
\text { Sampah }\end{array}$ & & \\
$\quad$ Ditimbun dalam & 10 & 20 \\
tanah & & \\
$\quad$ Dikumpul dan & 14 & 25,5 \\
dibakar & & \\
$\quad$ Disungai & 30 & 54,5 \\
$\quad$ Vektor Yang & & \\
Membahayakan & & \\
Lalat & 39 & 25 \\
$\quad$ Nyamuk & 36 & 38 \\
$\quad$ Anjing & 22 & 14 \\
$\quad$ Kecoa & 23 & 23 \\
\hline
\end{tabular}

Tabel 3 menunjukkan mayoritas penduduk lingkungan tidak bersih, 63\%, membungan sampah $54,5 \%$ di sungai Vektor yang membahayakan kesehatan terbanyak nyamuk $38 \%$, lalat $25 \%$, kecoa, $23 \%$, dan anjing $14 \%$ dari total kepala keluarga 54.

\section{Sarana Air Bersih dan Jamban}

Tabel 4. Distribusi Frekuensi ,Keadaan Air Bersih

\begin{tabular}{lcc}
\hline \multicolumn{1}{c}{ Karakeristik } & n & \% \\
\hline $\begin{array}{l}\text { Sumber Air Minum } \\
\quad \text { Mata Air }\end{array}$ & 54 & 100 \\
$\begin{array}{l}\text { Pengelolaan Air } \\
\text { Minum }\end{array}$ & & \\
$\quad$ Dimasak & 54 & 100 \\
Tempat Penyimpanan & & \\
\hline
\end{tabular}


Air

\begin{tabular}{lll} 
Terbuka & 26 & 48,2 \\
Tertutup & 28 & 51,8 \\
Keadaan Fisik Air & & \\
Jernih & 54 & 100 \\
\hline
\end{tabular}

Tabel 4 menunjukkan 100\% Air minum bersumber dari mata air, $100 \%$ dimasak tempat penyimpanan air tertutup $100 \%$, keadaan fisik air yang jernih sebanyak $100 \%$.

Tabel 5. Distribusi Frekuensi Sarana Jamban

\begin{tabular}{lcc}
\hline Karakeristik & n & $\%$ \\
\hline Tempat Pembuangan & & \\
Air Besar & & \\
$\quad$ Di Sungai & 7 & 14,5 \\
$\quad$ Diselokan & 4 & 7,3 \\
Di WC & 43 & 78,2 \\
\hline Kepemilikan Jamban & & \\
WC Umum & 23 & 42,6 \\
WC Pribadi & 20 & 37,1 \\
Tidak punya & 11 & 20,4 \\
\hline
\end{tabular}

Pembuangan Air

Limbah

Selokan

$14 \quad 25,9$

Sembarang tempat

Sungai

$28 \quad 51,9$

$12 \quad 22,2$
dan $7,3 \%$ parit., $42,6 \%$ jamban umum, $37,1 \%$ tidak memiliki jamban, 20,4\% memiliki jamban, Pembuangan air limbah $51,9 \%$ di sembarang tempat, $22,2 \%$ di sungai, dan $25,9 \%$ parit dari total kepala keluarga 54.

\section{Penyakit Yang Sering Dialami Penduduk}

Tabel 6. Penyakit Yang Sering Dialami Penduduk

\begin{tabular}{lcc}
\hline Kategori & n & \% \\
\hline DBD & 3 & 5,6 \\
Diare & 3 & 5,6 \\
Dermatitis & 6 & 9,3 \\
\hline
\end{tabular}

\begin{tabular}{lcc}
\hline ISPA & 17 & 31,5 \\
Malaria & 5 & 9,3 \\
Rheumatik & 2 & 3,7 \\
TB Paru & 19 & 35,0 \\
\hline
\end{tabular}

Tabel 6 menunjukkan penyakit yang sering dialami penduduk dalam 1 tahun terakhir (2013-2014) yaitu Tuberkulosis (TB) Paru 35,0\%, Infeksi Saluran Pernafasan Akut (ISPA) $31,5 \%$, Dermatitis seimbang dengan Malaria 9,3\%, Demam Berdarah Dengue (DBD) seimbang dengan Diare 5,6\%, Reumatik 9,3\% dari total penduduk 233 jiwa.

\section{Sumber Informasi danTempat Pelayanan Kesehatan}

Tabel 7. Sumber Informasi, dan Tempat Pemerikaan Kesahatan

\begin{tabular}{lcc}
\hline Karakeristik & n & \% \\
\hline \multicolumn{2}{l}{ Sumber Informasi Kesehatan } \\
Penyuluhan & 25 & 46,3 \\
PKM/Posyandu & \multicolumn{3}{c}{} \\
Radio & 14 & 25,9 \\
TV & 15 & 27,8 \\
Tempat Pemeriksaan Kesehatan \\
RS & 40 & $74,1 \%$ \\
Puskesmas & 8 & $14,8 \%$ \\
Tidak memeriksakan & 6 & $11,1 \%$ \\
\hline
\end{tabular}

Tabel 7 menunjukkan distribusi frekuensi penduduk memperoleh informasi kesehatan bersumber dari Puskesmas/Posyandu 46,3\%, Rumah Sakit 74,1\%. Pemeriksaan kesehatan menggunakan Rumah Sakit 74,1\% lebih tinggi dari Puskesmas 14,8\%, Tidak memeriksakan kesehatan ketika sakit $11,1 \%$ dari total keluarga 54 ..

\section{Pelayanan Kesehatan Balita}

Tabel 8. Pelayanan Kesehatan Balita Setiap Bulan

\begin{tabular}{lll}
\hline Karakeristik & n & $\%$ \\
\hline
\end{tabular}




\begin{tabular}{|c|c|c|}
\hline \multicolumn{3}{|c|}{ Penimbangan Bayi/Balita Setiap Bulan } \\
\hline $\mathrm{Ya}$ & 25 & 58,1 \\
\hline Tidak & 18 & 41,9 \\
\hline \multicolumn{3}{|l|}{ Kepemilikan KMS } \\
\hline Ada & 22 & 51,2 \\
\hline Tidak Ada & 21 & 48,8 \\
\hline \multicolumn{3}{|l|}{ Imunisasi Dasar } \\
\hline Lengkap & 18 & 41,9 \\
\hline Belum Lengkap & 8 & 18,6 \\
\hline Tidak Lengkap & 17 & 39,5 \\
\hline \multicolumn{3}{|c|}{ Pemberian Makanan } \\
\hline \multicolumn{3}{|l|}{ Tambahan } \\
\hline $\mathrm{Ya}$ & 38 & 89,4 \\
\hline Tidak & 5 & 11,6 \\
\hline
\end{tabular}

Tabel 8. menunjukkan balita yang ditimbang setiap bulan 58,1\%, memiliki kartu menuju sehat (KMS) hanya 51,2\%, mendapatkan imunisasi dasar baru 41,9\%, pemberian makanan tambahan $89,4 \%$ balita

Tabel 9. Penyakit Yang Sering dialami Balita

\begin{tabular}{lcc}
\hline Karakeristik & n & \% \\
\hline Demam & 10 & 23,3 \\
Diare & 8 & 18,6 \\
ISPA & 18 & 41,9 \\
Penyakit kulit & 3 & 7,0 \\
TB Paru & 4 & 9,3 \\
\hline
\end{tabular}

Tabel 9. menunjukkan penyakit yang sering dialami balita tertinggi ISPA $41,9 \%$, demam $23,3 \%$, diare $18,6 \%$, TBC 9,3\%, dan penyakit kulit $7,0 \%$ dari total balita 43 jiwa

\section{Pelayanan Keluarga Berencana}

Tabel 10. Pelayanan Keluarga Berencana

\begin{tabular}{lcc}
\hline Karakeristik & n & \% \\
\hline Pasangan Usia Subur Yang & & \\
Menggunakan Aseptor KB & & \\
Ya & 16 & 29,8 \\
Tidak & 38 & 70,2 \\
Jenis Penggunaan & & \\
Aseptor KB & & \\
\hline
\end{tabular}

\begin{tabular}{lcc}
\hline Implant & 1 & 1,9 \\
Kalender & 1 & 1,9 \\
Pil & 1 & 1,9 \\
Suntik & 13 & 24,1 \\
Tidak menggunakan & 38 & 70,2 \\
\hline
\end{tabular}

Tabel 10 menunjukkan distribusi frekuensi pasangan usia subur yang tidak menggunakan akseptor KB 70,2\% jauh lebih tingi dari yang menggunakan KB 29,8\%. Jenis kontrasepsi terbanyak menggunakan kontraspsi suntik 24,1\%, implant, pil dan kalender seimbang 1,9\%. Dari totak kepala keluarga 54.

\section{PEMBAHASAN}

\section{Karaktertik penduduk}

Tabel 1 menunjukkan mayoritas masyarakat berada pada rentang dewasa, dan perempuan, pekerjaan petani, tidak sekolah, dan Etnis Papua, agama Kristen Protestan, dan penghasilan perbulan Rp. $<500.000$. Keadaan ini merupakan faktor yang mempengaruhi kesehatan penduduk di RW 01 kelurahan Abepantai. Faktor kunci yang mempengaruhi kesehatan, yaitu keadaan individu: genetik, jenis kelamin, dan umur; status sosial ekonomi, pendidikan; jender (Public Health Agency of Canada, 2010 dalam Skolnic, 2012).

Genetik menandai suatu penyakit tertentu, misalnya penyakit Huntington yang merupakan gangguan system saraf, cancer payudara. Jenis kelamin mempunyai hubungan dengan penyakit tertentu, misalnya wanita berisiko terhadap melahirkan, cancer serviks, dan tyroid. Usia memiliki hubungan dengan kesehatan, anak-anak di negara berkembang sering meninggal akibat diare, sementara lansia meninggal karena penyakit jantung.

Isu sosial dan budaya juga berperan penting dalam menentukan kesehatan. Status sosial penting dalam menentukan kesehatan. Orang dengan status sosial tinggi lebih sering memeriksakan kesehatan dibandingkan orang berstatus sosial ekonomi lemah, orang berstatus sosial tinggi juga memiliki pendapatan dan 
menetapkan kebijakan tentang jaminan

pendidikan tinggi, kesemua itu memiliki hubungan yang kuat dengan kesehatan yang baik. Budaya juga memiliki hubungan yang kuat dengan kesehatan. Budaya membantu menentukan bagaimana seseorang merasakan sehat dan sakit, bagaimana cara menggunakan pelayanan kesehatan, dan praktek kesehatan dimana mereka berada.

Pendidikan merupakan faktor kuat berhubungan dengan kesehatan karena berbagai alasan. Pertama menjembatani pengetahuan terhadap praktek kesehatan. Kedua, memberi kesempatan memperoleh keterampilan, dan pekerjaan terbaik, meningkatkan pendapatan seseorang, dan meningkatkan status sosial. Ada hubungan yang kuat antara level pendidikan dengan seluruh indikator kesehatan. Orang yang berpedidikan baik akan makan baik, sedikit merokok, sedikit gemuk, memiliki sedikit anak, dan melakukan perawatan kesehatan anak dengan baik dibandingkan orang yang berpendidikan kurang. Oleh sebab itu anak mereka berusia panjang dan hidup dengan sehat daripada yang dilakukan oleh orang yang berpendidikan rendah (Skolnic, 2012).

Program Indonesia Sehat yaitu meningkatkannya derajad kesehatan dan status gizi masyarakat melalui upaya kesehatan dan pemberdaayaan masyarakat yang didukung dengan perlindungan finasial dan pemerataan pelayanan kesehatan. Juga sasaran program rencana pembangunan jangka menengah (RPJPM) 2015/2019, yaitu: (1) meningkatkan kesehatan dan gizi ibu dan anak; meningkatknya pengendalian penyakit; (2) meningkatnya akses dan mutu pelayanan kesehatan dasar dan rujukan terutama di daerah terpenci, tertinggal dan perbatasan; (3) meningkatnya cakupan pelayanan kesehatan universal melalui Kartu Indonesia Sehat dan kualitas pengelolaan sistem jaminan kesehatan nasional (SJKN) kesehatan; terpenuhinya kebutuhan tenaga kesehatan, obat, dan vaksin; serta meningkatnya responsibilitas sistem kesehatan. Khusus untuk etnis papua pemerintah Provinsi Papua juga telah kesehatan khusus bagi orang asli Papua (Jamkespa).

\section{Karakteritik Rumah, dan Kebersihan Lingkungan}

Tabel 2,3 menujukkan risiko tinggi kejadian penyakit ISPA, malaria, Diare, dan DBD, dan kulit. Hal ini ditunjukkan dengan kondisi lingkungan dan tempat tinggal penduduk belum sesuai dengan rumah sehat. Syarat rumah sehat yaitu (1) tidak terbuat dari bahan yang berbahaya, (2) tidak ada genangan air, (3) kamar tidur tidak gelap di siang hari, (4) dapur bersih dan bebas tikus, (5) berventilasi, (6) televisi berada di ruangan yang cukup cahaya, (7) memiliki tempat penyimpnan makanan yang bersih, (8) kamar mandi kedap air, (9) langit-langit bersih dana man, (10) cukup air (Swastantika, 2017). Kondisi rumah penduduk di RW 01 belum sesuai dengan 10 syarat rumah sehat. Ukuran rumah yang kecil sekitar 2,5 meter $\mathrm{x} 3$ meter, ada rumah beralaskan karpet yang langsung diletakkan diatas tanah tanpa diplester, dan tanpa kayu atau papan, ventilasi dan pencahayaan yang kurang memadai, didukung dengan rumah tidak memiliki plapon sangat tidak layak dihuni bagi keluarga yang memiliki anggota keluarga lebih dari 3 orang, memasak dalam rumah menggunakan tungku kayu. Kondisi rumah yang tidak layak huni disebabkan oleh masalah kepemilikan tanah (hak ulayat) dimana $100 \%$ penduduk di RW 01 merupakan pendatang dari kabupaten Mamberamo. Mereka sulit memiliki tanah karena tidak mendapatkan ijin dari pemilik tanah adat setempat untuk mendirikan rumah yang layak huni. Oleh sebab itu perlu kebijakan pemerintah agar ada kesepakatan bagi pemilih tanah adat (Ondoafi) untuk pembebasan lahan sehingga masyarakat di RW 01 dapat menempati rumah yang sesuai standar kesehatan.

Kebersihan lingkungan masyarakat RW 01 Kelurahan Abepantai dipengaruhi oleh 
berisiko terhadap penyakit infeksi, cidera,

beberapa faktor, yaitu perilaku masyarakat yang membuang sampah sembarangan, tidak tersedianya sarana kebersihan dan saluran air limbah yang memadai, serta daya beli masyarakat rendah akibat penghasilan yang rendah, dan waktu untuk menata lingkungan terbatas, sebab sebagain waktu berada dikebun dimana warga mulai berangkat ke kebun sekitar jam 5.00 pagi dan kembali ke rumah pada pukul 14.00 dan langsung menjual hasil kebunnya ke pasar. Mereka akan berada dirumah berkumpul dengan anggota keluarga sekitar jam 19.00. Bagi mereka yang belum memetik hasil kebun akan berada di kebun sejak jam 5.00 pagi hingga jam 17.00. Untuk mendukung kebersihan lingkungan diperlukan kebijakan dan peraturan pemerintah serta dukungan segenap komponen masyarakat untuk menata kebersihan lingkungan sebagai salah satu cara menurunkan angka kejadian penyakit seperti diare, malaria, dan tuberculosis.

Lingkungan fisik: air, sanitasi, polusi udara; serta kebijakan pemerintah dan intervensi merupakan faktor yang mempengaruhi kesehatan (Public Health Agency of Canada,2010 dalam Skolnic, 2012). Baik lingkungan dalam gedung maupun luar gedung kuat mempengararuhi kesehatan. Polusi didalam dan diluar gedung berpengaruh terhadap kesehatan. Di beberapa Negara berkembang wanita memasak dalam rumah yang dipenuhi dengan asap memicu terjadinya penyakit sistem pernafasan dan asma. Sanitasi merupakan suatu masalah utama yang berkonstribusi terhadap kesehatan buruk negara. Juga, beberapa orang bekerja di lingkungan yang sangat tidak sehat. Karena mereka tidak terampil, status sosial rendah, dan kesempatan, mereka bekerja dengan zat kimia berbahaya, atau pulusi udara, tanpa perlindungan yang memadai atau berbagai peristiwa paparan terhadap kecelakaan kerja (Skolnic, 2012).

Rumah yang padat dengan penghuni, konstruktinya kurang baik, kotor, penuh dengan serangga, terpapar asap rokok, kondisinya buruk penyenyakit system cardiovasculadan gangguan system pernafasan, kanker, alergi,sakit kepala dan gangguan kesehatan mental, serta risiko kebakaran (The U.S. Departmenet of Human Servives, 2000., Environment Protection Agency, dalam Nies., \& McEwen, 2007). Kesemuanya ini merupakan masalah kesehatan lingkungan. Kesehatan lingkungan adalah semua aspek dari kesehatan manusia, penyakit, dan cidera yang dipengaruhi oleh faktor lingkungan. Semua aspek ini mencakup penelitian dari dampak lansung patologi dari agen kimia, pisika, dan biologi dan berdampak terhadap kesehatan secara luas dari fisik, lingkungan social yang mencakup rumah, pengemebangan kota, penggunaan lahan, transportasi, industry, dan pertanian (The U.S Department oh Human Services, 2000 dalam Nies., \& McEwen, 2007).

Undang-undang Nomor 36 tahun 2009 tentang Kesehatan Lingkungan menegaskan bahwa upaya kesehatan lingkungan ditujukan untuk mewujudkan kualitas lingkugan yang sehat, baik fisik, kimia, biologi, maupun sosial yang memungkinkan setiap orang mencapai derajad kesehatan yang setinggi-tingginya. Lingkungan sehat mencakup lingkungan pemukiman, tempat kerja, tempat rekreasi, serta tempat dan fasilitas umum, harus bebas dari unsur-unsur yang menimbulkan gangguan diantaranya limbah (cair, padat, dan gas), sampah yang tidak diproses sesuai sesuai dengan persyaratan, vektor penyakit, zat kimia berbahaya, kebisingan yang melebihi ambang batas, radiasi, air, yang tercemar, udara yang tercemar dan makanan yang terkontaminasi (Kemekes RI, 2009).

\section{Sarana Air Bersih dan Jamban}

Tabel 4 dan 5 menunjukkan $100 \%$ penduduk menggunakan air bersih untuk keperluan mamasak, mencuci dan mandi bersumber dari mata air. Hasil penelitian ini bertentang dengan hasil Riskesdas bahwa jenis 
dan dapat langsung diminum. Air minum aman

sumber air untuk seluruh kebutuhan rumah tangga di Indonesia pada umumnya adalah sumur gali terlindung 29,2\%, sumur pompa $24,1 \%$ dan air ledeng/PDAM 19,7\% (Riskesdas 2013 dalam Angka). Di perkotaan, lebih banyak rumah tangga yang menggunakan air dari sumur bor/pompa 32,9\% dan air ledeng/PDAM(28,6\%, sedangkan di perdesaan lebih banyak yang menggunakan sumur gali terlindung 32,7\%. (Riskesdas 2013).

Sementara penggunaan jamban masih ada di sungai, dan parit karena tidak memiliki jamban. Demikian juga pembuangan air limbah belum tertata dengan rapi sesuai satandar, sebagain besar penduduk membuang di sembarang tempat, yang lain di sungai dan parit. Sumber air bersih yang digunakan oleh penduduk RW 01 berasal dari mata air pegunungan, namun belum dikelaloh dengan baik. Masyarakat di RW 01 semuanya (10\%) memanfaatkannya sebagai sumber air minum, diamsping menggunakan air minum dari air gallon atau mineral yang dibeli di Toko atau warung setempat Oleh sebab itu perlu dikelola oleh perusahaan air mimun daerah (PDAM), koperasi, atau masyarakat agar dapat terjamin kualitasnya. Sesuai dengan standar.

Air dibutuhkan untuk seluruh kehidupan. $75 \%$ tubuh manusia terdiri dari air Air digunakan untuk memasak. (Stanhope \& Lancaster, 2004). Ketersediaan sumber air bersih memberikan manfaat bagi masyarakat dalam menata kebersihan lingkungan dan rumah tempat tinggal. Air dan sanitasi merupakan salah faktor yang berhubungan dengan masalah kesehatan (Public Health Agency of Canada, 2010 dalam Skolnic, 2012). Kekurangan air minum yang aman merupakan suatu masalah utama yang berkonstribusi terhadap kesehatan buruk Negara (Skonic, 2010). Peraturan Menteri Kesehatan Nomor 492/MENKES/PER/IV/2010 tentang Persyarakatan Kualitas Air Mimun, dijelaskan bahwa air minum adalah air yang melalui proses pengolahan atau tanpa proses pengolahan yang memenuhi syarat kesehatan bagi kesehatan apabila memenuhi persyaratan fisika, mikrobiologi, kimiawi dan radioktif yang dimuat dalam parameter wajib dan parameter tambahan. Secara fisik air minum yang sehat adalah tidak berbau, tidak berasa, tidak berwarna, serta memiliki total zat padat terlarut dan suhu sesuai ambang batas. Secara mikrobiologis air minum yang sehat harus terbebas dari E.coli dan total bakteri koliform. Secara kimiawi zat kimia yang terkandung dalam air minum besi, almunium, klor, arsen, dan lain-lain harus dibawah ambang batas yang ditentukan. Secara radioaktif, kadar gross alpha activity tidak boleh melebihi 0,1 per liter (Bq/l) dan kadar gross beta activity tidak boleh melebihi 1 Bq/l (Setyoningsih, 2010). Oleh sebab itu disarankan kepada puskesmas untuk melakukan pemeriksaan air yang bersumber dari mata air dan digunakan masyarakat sebagi kebutuhan sehari-hari.

Masih adanya masyarakat yang tidak menggunakan jamban kerena faktor kemiskinan, dan penggunaan lahan yang terbatas karena masalah kepemilikan lahan oleh pemangku adat dimana tidak semua orang dapat memiliki lahan baik dengan cara diperjualbelikan sehingga ada masyarakat yang hanya boleh tinggal diatas tanah dengan ukuran 3x 4 meter. Oleh sebab itu perlu ada kebijakan dan kesepakatan aanatara pemangku kebijakan, pemangku adat untuk membelikn tempat tinggal yang layak bagi penduduk di Rw 01. Masyarakat juga perlu diberdayakan dalam pengelolaan sumber air bersih secara maksimal. Perlu kebijakan dan perturan pemerintah setempat berkerjasama dengan pimpinan Puskesmas Abepanatai mewajibkan bagi semua penduduk menggunakan jamban untuk toileting. Buang air besar disembarang tempat berisiko terhadap kajadian diare (Public Health Agency of Canada,2010 dalam Skolnic, 2012).

Beberapa penelitian menujukkan ada hubungan yang signifikan antara kepemilikan jamban dan ketersediaan sarana air bersih 
orang baik laki-laki ataupun perempuan pada

dengan kejadian diare. Rachmawati (2012) melaporkan sekitar $66,7 \%$ balita mengalami diare yang tidak memiliki jamban lebih tinggi dari yang memiliki jamban 11,3\%; yang memiliki jamban tidak diare $88,9 \%$ lebih tinggi daripada yang tidak memiliki jamban 33,4\%; Ada hubungan signifikan antara kepemilikan jamban dengan kejadian diare $(\mathrm{p}=0,000 ; \alpha<$ 0,05). Fajriani (2016) melaporkan $40 \%$ balita tidak mengalami diare dengan adanya ketersediaan air bersih, sedangkan yang tidak tersedia sarana air bersih $85,7 \%$ balita mengalami diare; Ada hubungan signifikan antara ketersediaan sarana air bersih dengan kejadian diare $(\mathrm{p}=0,000 ; \alpha<0,05)$. Perlu dilakukan promosi kesehatan secara terus menerus untuk meningkatkan perubahan perilaku masyarakat, bisa melalui media massa, social marketing, pendidikan kesehatan, dan bantuan biaya Menurut (Skolnik, 2010) media massa, sering digunakan untuk mempromosikan perubahan perilaku. Pada kebanyakan orang di Negara dengan ekonomi rendah mengakses promosi perubahan kesehatan melalui radio. Disamping social marketing, pendidik kesehatan, bantuan biaya.

\section{Penyakit Yang Sering Dialami Penduduk Dalam Satu Tahun Terakhir}

Tabel 6 menunjukkan ketidakefektifan pelayanan kesehatan masyarakat. Hal ini ditunjukkan dengan adanya penyakit yang sering dialami penduduk dalam 1 tahun terakhir (2013-2014) yaitu Tuberkulosis (TB) Paru $35,0 \%$ separuh dari perkiraan insidensi nasional kasus hilang $68 \%$ antara tahun 2010 dan 2014 (Kemenkes, 2006); Infeksi Saluran Pernafasan Akut (ISPA), Dermatitis. Malaria, Demam Berdarah Dengue (DBD), Diare; dan Reumatik.

Malaria adalah penyakit infeksi yang disebabkan oleh parasit plasmodium yang hidup dan berkembang biak dalam sel darah merah manusia, ditularkan oleh nyamuk malaria (Anopeles) betina, dapat menyerang semua semua golongan umur dari bayi, anak-anak, dan orang dewasa. Kasus malaria yang temukan pada penduduk RW 01 Kelurahan Abepantai 9,3\% lebih rendah dari angka Papua tahun 2015 sebesar 31,93\% (Kemenkes, 2016). Namun kejadian malaria perlu mendapat perhatian serius sebab masih merupakan salah satu penyeb kematian di Papua. Malaria disebabkan karena kondisi lingkungan perumahan dimana rumah tidak tertutup rapat, seperti tidak ada penutup jendela, ada celah antara dinding dan lantai rumah, tidak menggunakan plafon, kurang cahaya, lembab, dan pakaian bergelantungan.

Demam Berdarah Dengue (DBD) adalah penyakit yang disebabkan oleh virus dengue yang tergolong Artroda-Borne Virus, genus Flavirus, dan family Plaviridea. DBD ditularkan melalui gigitan nyamuk dari genus Aedes, terutama Aedes aegypti atau Aedes albopictus. Penyakit DBD dapat muncul sepanjang tahun dan dapat menyerang seluruh kelompok umur. Penyakit ini berkembang dengan kondisi lingkungan dan perilakau masyarakat. Kejadian DBD di RW 01 sebesar 5,6\% . Angka ini lebih rendah dari angka Papua 20,54\% dan Nasional $84,74 \%$ tahun 2014 dan 86,77\% tahun 2015 (Kemkes, 2016).

Penyakit diare menurut (Kemenkes, RI, 2016) merupakan penyakit endemis di Indonesia dan merupakan penyakit potensil kejadian luar biasa (KLB) yang sering disertai dengan kematian. Pada tahun 2015 terjadi 18 kali KLB Diare yang tersebar di di 11 provins, 18 kabupaten/kota dengan jumlah penderita 1.213 orang dan kematian 30 orang (CFR 2,47\%). Kejadian diare di RW 01 sebesar 5,6\%. Angka ini lebih rendah dari angka Papua $166,6 \%$ dan nasional 74,4\%. Kejadian diare akibat perilaku masyarakat jamban di kali, selokan, karena belum memiliki jamban serta terbatasnya kepemilikan lahan akibat kepemilikan adat (hak ulayat).

Dermatitis adalah peradangan kulit epdermo-dermitis dengan gejala subyektif 
2010 menetapkan 10 indikator sehat dan

pruritis. Objektif tampak inflamasi eritema, vesikulasi, eksudasi, dan pembentukan sisik. Tanda-tanda tersebut tidak selalu timbul pada saat yang sama. Penyakit bertendensi residif dan menjadi kronik (Djunda, 1993). Adanya kejadian dermatitis pada penduduk RW 01diduga karena kurang kebersihan, namun perlu dilakukan penelitian lebih lanjut tentang penyebabnya. Berdasarkan pengamatan dilapangan beberapa keluarga yang ditemukan ketika survey pakaian nampak kotor, sementara anak-anak mandi di saluran air saat hujan.

Reumatik atau Artritis merupakan penyakit yang menyerang persendian dan struktur disekitarnya . Jika tidak segera ditangai dapat menyebabkan anggota tubuh berfungsi tidak normal, mulai dari benjol-benjol, sendi kaku, sulit berjalan, bahkan kecacatan seumur hidup (Olwin, 2009). Jumlah kasus Reumatik di RW 01 sebanyak 3,7\% . Angka ini lebih rendah dibandingkan angka Papua 28,8\% dan nasional 32,7\% tahun 2007 (Olwin, 2009). Kejadian reumatik diduga ada hubungnya dengan faktor usia dan pekerjaan, dimana semua pasien reumatik telah berusia diatas 50 tahun dan bekerja sebagai nelayan. Bagi penduduk RW 01 Kelurahan Abepantai. Namun untuk mengetahui penyebb pasti keadian reumatik pada penduduk RW 01 perlu dilakukan penelitian tentang faktor risiko kejadian reumatik Walaupun angka reumatik di RW 01 rendah namun perlu dilakukan penangnanan sedini mungkin untuk mencegah kecacatan dikemudian hari.

Tingginya masalah kesehatan menunjukkan status kesehatan masyarakat di RW 01 Kelurahan Abepantai masih rendah. Status kesehatan merupakan istilah umum yang merujuk pada kesehatan (baik atau buruk) dari seseorang, kelompok atau populasi dalam suatu area khusus, khususnya bila dibandingkan dengan data nasional (Segen's Medical Dictionary, 2012).

Pencapaian indikator sehat bagi penduduk di RW 01 Kelurahan Abepantai belum sesuai harapan. Sehat bagi penduduk penyakit, yaitu perilaku individu (misalnya aktivitas fisik, kelebihan berat badan dan kegemukan, pemakaian tembakau, penggunaan alcohol, perilaku seksual); faktor lingkungan sosial dan fisik (misalnya kualitas lingkungan, cidera, dan kekerasan); dan sistem kesehatan (misalnya akses terhadap pelayanan kesehatan); kesehatan mental, imunisasi. Setiap indikator ini berhubungan dengan penyebab kesakitan dan kematian. Misalnya pemakaian tembakau berhubungan dengan penyakit jantung, strok, dan kanker; penyalahgunaan obat berhubungan dengan kecelakaan, cidera, dan kekerasan; perilaku seksual bebas berhubungan dengan penyakit menular seksual mencakup HIV/AIDS; dan kurang jangkauan pelayanan kesehatan berkonstribusi terhadap hasil kehamilan yang buruk, penyakit tidak diobati, dan kecacatan (Nies; \& Mc.Ewen, 2007).

Belum tercapainya indikator sehat bagi penduduk di RW 01 Abepantai karena berbagai faktor risiko. Faktor risiko adalah suatu keadaan atau perilaku yang dihubungkan dengan peningkatan frekuensi penyakit tetapi bukan sebagai penyebab (Whitney \& Rolfes, 2011), mencakup faktor paparan spesifik seperti: merokok, stress berat, suara yang terlalu keras, atau lingkungan kimia (Nies \& McEwen, 2007). Menurut (Edeleman \& Mandle, 2011; Stanhope dan Lancaster, 2004), faktor risiko kesehatan keluarga yaitu: gaya hidup, biologi, lingkungan, sosial psikologi, budaya, dan spriritual; dan 5) sistem pelayanan kesehatan. Nies dan McEwen (2007) menjelaskan bahwa faktor risiko meliputi karakteristik individu seperti: umur, jenis kelamin, atau genetik, dan gaya hidup.

Faktor risiko yang berhubungan dengan kesehatan masyarakat (penyakit, angka kesakitan dan kematian) yaitu: demografi, psikologi, psikososial, dan lingkungan, misalnya umur, gender, ras, letak geografis, pola konsumsi, kurangnya pelayanan kesehatan (Edelman., \& Mandle, 2010). Faktor risiko 
Puskesmas. Masih ada yang tidak melakukan

kejadian TBC dan ISPA, malaria, diare, DBD, dan penyakit kulit pada penduduk RW 01 yaitu perilaku penduduk merokok dalam rumah, konsumsi minuman beralkohol, konstruksi rumah dimana pencahayaan kurang, ventilasi, tidak menggunakan plafond, memasak menggunakan tungku kayu dalam rumah, tidak tersedia saluran air limbah rumah tangga yang memadai, perilaku pencarian kesehatan dimana apabila ada anggota keluarga yang TBC dan ISPA enggan berobat ke Puskesmas, dan bila ada yang berobat tidak tuntas (putus minum obat TBC). perilaki masyarakat buang besar di sungai dan parit, membuang sampah ke sungai dan disembenrang tempat, keterbatasan kepemilikian jamban, serta vector yang membahayakan kesehatan seperti nyamuk dan hewan peliharaan lainnya, akses terhadap informasi kesehatan.

Untuk mencegah faktor rsiko diperlukan dukungan dan peran serta masyarakat. Peran tokoh masyarakat dan tokoh agama sangat penting dalam upaya meningkatkan status kesehatan masyarakat. Sehingga dapat dijadikan mitra dalam pengambilan kebijakan pembangunan kesehatan. Adanya kerjasama dari segenap komponen yang ada di masyarakat RW 01 berpeluang dilakukan pemberdayaan masyarakat melalui kerjasama berbagai lintas program dan sektor. Namun, pelayanan kunjungan ke rumah perlu lebih ditingkatkan dalam rangka pelaksanaan perkesmas sesuai Keputusan Menkes RI No: 27/Menkes/SK/IV/2006 Tgl 21 April 2006 tentang perkesmas. Disamping, perlu proaktif dari petugas Puskesmas untuk melakukan kunjungan rumah kunjungan rumah.

\section{Sumber Informasi dan Tempat Pelayanan Kesehatan}

Tabel 7 menunjukkan mayoritas penduduk memperoleh informasi kesehatan bersumber dari Rumah Sakit lebih tinggi dari Puskesmas/Posyandu. Pelayanan kesehatan menggunakan Rumah Sakit, lebih tinggi dari pelayanan kesehatan ketika sakit. Tingginya informasi masyarakat memperolah informasi dan mendapatlakan pelayanan kesehatan di rumah sakit disebabkan waktu pelayanan Pukesmas terbatas dari jam 7.30 hingga jam 15.00, sebagaian besar warga bertani dan berada sehingga tidak memiliki waktu untuk berobat ke Puskesmas, tetapi langsung ke rumah sakit. Sementara penduduk yang tidak berobat karena ada persepsi yang salah akan masalah kesehatan seperti ketika sakit dianggap sebagai buatan orang yang iri, benci, dan tidak senang, atau takut dengan keputusan dokter tentang diagnosis penyakit yang dialami. Oleh sebab itu perawat puskesmas perlu menigkatkan jangkauan pelayanan kesehatan kepada masyarakat RW 01 melalui kunjungan rumah dan penyuluhan kesehatan di gereja.

Untuk menyelenggarakan upaya kesehatan yang efektif dan efisien diperlukan informasi keehatan. Informasi kesehatan dilakukan melalui system informasi dan melalui lintas sektor. Pemerintah memberikan kemudahan kepada masyarakat untuk memperoleh akses terhadap informasi kesehatan dalam upaya meningkatkan derajad kesehatan masyarakat (Kemenkes RI, 2009).

Pelayanan kesehatan merupakan upaya kesehatan yaitu setiap kegiatan dan atau serangkaian kegiatan yang dilakukan secara terpardu, terintegrasi, dan berkesinambungan untuk memeliharu dan meningkatkan derjat kesehatan masyarakat dalam bentuk pencegahan penyakit, peningkatan kesehatan, pengobatan penyakit. Dan pemulihan kesehatan oleh pemerintah dan/atau masyarakat. Pelayanan kesehatan terdiri dari pelayanan kesehatan perorangan dan pelayanan kesehatan masyarakat. Pelayanan kesehatan meliputi kegiatan dengan pendekatan promotif, preventif, kuratif, dan rehabilitatif. Pelayanan kesehatan perorangan ditujukan untuk penyembuhan penyakit dan memulihkan kesehatan perorangan dan keluarga. Pelayanan kesehatan masyarakat 
ditujukan memelihara dan meningkatkan kesehatan kesehatan serta serta mencegah penyekait suatu kelompok masyarakat (Kemenkes, 2009).

Perawat dapat memberikan infomasi kesehatan bagi klien ketika melakukan kunjungan rumah. Misalnya ketika melakukan kunjungan rumah bagi klien dengan malaria, maka perawat memberikan informasi tentang malaria mencakup pengertian, penyebab, tanda, gejala dan pencegahan. Perawat juga dapat melakukan pemeriksaan sederhana ketika melakukan kunjungan rumah pada klien dengan malaria dan melakukan rujukan ke fasilitas kesehatan yang memadai. Kementerian Kesehatan (Kemekes,2016) telah menetapkan kebijakan pendekatan keluarga dalam pencapaian prioritas pembangunan kesehatan. Pendekataan keluarga adalah salah satu cara puskesmas untuk meningkatkan akses pelayanan kesehatan di wilayah kerjanya dengan mendatangi keluarga. Puskesmas tidak hanya menyelenggarakan pelayanan kesehatan di dalam gedung melainkan juga di luar gedung dengan mengunjungi keluarga di wilayah kerjanya.

\section{Pelayanan Kesehatan Balita}

Tabel 8 menunjukkan ketidakefektifan pelayanan kesehatan Balita, dan Risiko tinggi infeksi saluran pernafasan akut, dan diare. Hal ini ditunjukkan dengan pelayanan kesehatan balita mencakup penimbangan setiap bulan, pemberian kartu menuju sehat (KMS), pemberian imunisasi dasar masih rendah, kecuali pemberian makanan tambahan sudah baik Pelayanan kesehatan balita setiap bulan dilaksanakan di Posyandu. Penyakit yang dialami baliata ISPA, demam, diare, TB Paru, dan kulit.

Cakupan penimbangan balita di posyandu (D/S) adalah jumlah balita yang ditimbang di seluruh posyandu yang melapor di satu wilayah kerja pada kurun waktu tertentu. Peran serta masyarakat dalam penimbangan balita sangat penting dalam deteksi dini kasus gizi kurang dan gizi buruk. Dengan rajin menimbang balita, maka pertumbuhan balita dapat dipantau secara intensif. Sehingga bila berat badan anak tidak naik ataupun jika ditemukan penyakit akan segera dilakukan upaya pemulihan dan pencegahan supaya tidak menjadi gizi kurang atau gizi buruk akan semakin baik. Penanganan yang cepat dan tepat sesuai tatalaksana kasus gizi buruk akan mengurangi risiko kematian sehingga angka kematian akibat gizi buruk dapat ditekan. Cakupan balita yang ditimbang setiap bulan di Rw 01 Kelurahan Abepantai baru mencapai $58,1 \%$ lebih rendah dari cakupan nasional tahun 2015 73,0\%, namun lebih tinggi dari Papua 25,0\% (Kemkes, 2016).

Program imunisasi pada balita bertujuan agar setiap bayi mendapatkan imunisasi dasar secara lengkap. Keberhasilan seorang bayi dalam mendapatkan imunisasi tersebut diukur melalui indikator imunisasi dasar lengkap. Capaian imunisasi lengkap di RW 01 Kelurahan Abepantai 41,9\% sedikit rendah dari angka Provinsi 47,27\% dan nasional pada tahun 2015 sebesar 86,5\% serta target Rentra 2015 91\%. Semnetara menurut indicator keberhasilan pelaksanaan imunisasi Universal Child Immunisation (UCI) desa/kelurahan $\geq 80 \%$ dari jumlah bayi 0-11 bulan yang ada di desa atau kelurahan tersebut sudah mendapat imunisasi dasar lengkap (Kemenkes, 2016).

Belum maksimalnya pelayanan kesehatan balita disebabkan berbagai faktor diantaranya pendidikan ibu yang rendah, serta kurangnya kesadaran akan pentingnya membawa balita ke posyandu dan imunisasi dasar. Hal ini didukung dengan peran ganda ibu sebagai pengasuh balita adan pencari nafkah bagi keluarga sebagai petani yang selanjutnya menjajakan hasil kebun ke pasar untuk memenuhi kebutuhan keluarga. Untuk mengatasi hal tersebut Puskesmas harus bisa mengatur waktu kegiatan Posyandu sesuai dengan kegiatan masyarakat RW 01. 
diperlukan untuk aliran darah dan menjaga agar

Infeksi saluran pernafasan akut (ISPA) menurut World Health Organisastin (WHO) umumnya ditularkan melalui droplet. Namun pada sebagian pathogen ada juga kemungkinan penularannya melalui cara lain seperti kontak dengan tangan atau permukaan yang terkontaminasi (WHO, 2008). Kasus ISPA pada balita sebesar $41,9 \%$ sedikit lebih tinggi dari seluruh kasus ISPA di RW 01 sebesar 35,1\%, dan Puskesmas Abepantai sebesar $40 \%$. Sehingga, pencegahn akan kejadian ISPA sangat penting dilakukan promosi kesehatan oleh petugas Puskesmas seperti perilaku Hidup Bersih dan Sehat: mencuci tangan, menggunakan masker ketika batuk), disamping panataan lingkungan rumah. WHO (2008 telah mengeluarkan Pedoman Ringkas tentang Pencegahan dan pengedalian ISPA di fasilitas pelayanan kesehatan yang berisi tentang rekomendasi penting yaitu: laporkan segera setiap kasus suspek ISPA yang dapat menimbulkan kekuatiran termasuak severe acute respiratory syndrome (SARS), dan infeksi flu burung pada manusia kepada dinas kesehatan yang berwenang; segera isolasi pasien suspek ISPA dari pasien dan pastikan mereka mendapat perawatan dan terapi yang tepat; lakukan kewaspadaan standar saat memberikan pelayanan kepada pasien baik diagnosis confirm ataupun suspek. Tindakan kewaspadaan Standar adalah langkah dasar pencegahan dan pengendalian infeksi dalam pelayanan kesehatan dan harus selalu dilakukan saat memberikan pelayanan pada pasien; lakukan kewaspadaan transmisi droplet; lakukan kewaspadaan transmisi kontak lakukan kewaspadaan transmisi airborne; Upayakan ventilasi pada lingkungan pasien untuk mengurangi risiko penularan penyakit melalui aerosol pernafasan.

Demam adalah keadaan suhu tubuh di atas $30^{\circ}$ Celsius. Suhu tubuh adalah suhu visera, hati, otak, yang dapat diukur lewat rektal, dan aksila. Cara pengukuran suhu menentukan tinggi rendahnya suhu tubuh. Suhu tuubuh adalah hasil produksi metabolism tubuh yang reaksi kimia tubuh dapat berjalan baik (enzim hanya bekerja pada suhu tertentu). Penyeb demam merupakan akibat dari kenaikan set point (oleh sebab infeksi) atau oleh adanya ketidakseimbangan antara produksi panas dan pengeluarannya (Lubis., \& Lubis, 2011).

Diare merupakan kondisi yang ditandai dengan encernya tinja yang dikeluarkan dengan frekuensi buang air besar yang lebih sering dibandingkan dengan biasanya. Pada umunya diare terjadi akibat konsumsi makanan atau minuman yang terkontaminasi bakteri, virus, atau parasite. Biasanya diare hanya berlangsung beberap hari, namun pada sebagain kasus memanjang hingga berminggu-minggu (Alodokter.com, 2016). Kejadin diare pada balita sebesar 18,6\% lebih tinggi dari angka RW 01 sebesar 5,6\%, dan Puskesmas 7,4\%. Perlu dilakukan penelitian lebih lanjut tentang faktor risiko kejadian diare bagi penduduk di Kelurahan Abepantai dan kebijakan tentang pencegahan diare melaui penataan kebersihan lingkungan sarana air minum, pembunagn limbah, dan penagadaan jamban bagi penduduk yang belum memilik jamban malalui kerjasama lintas sector dan lintas program.

Tuberkulosis merupkan penyakit merupakan penyakit menular yang disebabkan oleh infeksi bakteri Mycobacterium Tuberculosis. Sumber penularan yaitu pasien TB BTA (bakteri tahan asam) positif melalui percik renik dahak yang dikeluarkannya. TB dengan BTA negative juga masih memiliki kemungkinan menularkan penyakit TB meskipun dengan tingkat penularan yang kecil. Kasus TB paru berdasarkan riwayat penyakit dan telah mendapatkan pengobatan pada balita di RW 01 Kelurahan Abepantai sebesar 9,3\% lebih rendah dari total kasus TB d RW 01 sebesar 35,0\% dan mendekati angka Papua tahun 2013 sebesar 45,4\% (Abubar,2015), Papua tahun 2015 sebesar 37,0\% dan target minimal Nasional 70\% (Kemenkes, 2016). Untuk mencegah penularan TB paru perlu 
Pekerjaan Umum Kota Jayapura, Pemangku

penataan kembali pemukiman penduduk agar sesuai dengan standar kesehatan.

\section{Pelayanan Keluarga Berencana}

Tabel 9 menunjukkan pelayanan kesehatan keluarga berencana masih rendah dimana peserta baru mencapai 29, 8\% lebih rendah dari angka Papua 52,99\% dan angka nasional $75,10 \%$. Rendahnya pelayanan KB karena kesadaran masyarakat masih kurang akibat kurang terpapar informasi serta persepsi masyarakat bahwa bila mengikuti BK penduduk asli Papu akan berkurang bahkan punah, waktu terbatas karena separuh waktu habis digunakan di Kebun dan berjualan ke pasar. Selain, peserta harus membeli sendiri obat suntik atau pil jika tidak tersedia di Puskesmas. Untuk meningkatkan motivasi masyarakat pentingnya mengikuti KB perlu ada kebijakan dan peraturan perundang-undangan tentang pelaksanaan $\mathrm{KB}$. Disamping, petugas puskesmas bersama kader memberikan informasi kesehatan secara terusmenerus baik di Puskesms maupun di Posynadu atau melalui kunjungan rumah.

Metode kontrasepsi terbanyak adalah suntik 24,1\%, mendekati angka papua 36,82\% dan namun masih rendah angka nasional 49,93\%. implant, pil dan kalender seimbang 1,9\% jauh dibawah angka Papua 6, 16\% dan nasional 9,63\% (Kemenkes RI, 2016). Pelayanan kesehatan dalam KB dimaksudkan untuk pengaturan kehamilan bagi pasangan usia suburuntuk mebentuk generasi penerus yang sehat dan cerdas (Kemenkes RI, 2009).

\section{KESIMPULAN}

Status kesehatan penduduk di RW 0101 Kelurahan Abepatai Abepura Kota Jayapura masih rendah.

\section{SARAN}

Disarankan untuk meningkatkan status kesehatan penduduk dalam mengakses kesehatan, memperbaiki lingkungan pemukiman penduduk melalui kerjasama Departemen
Adat (Ondoafi), Pihak Swasta, dan Akademik atau institusi pendidikan.

\section{KEPUSTAKAAN}

Abubar, M. 2015. Kasus TBC di papua tercatat sebanyak 5550 kasus. Antara papua.[online]. https://papua.antarnew.com.Diakses 19 Juni 2018.

Allodokter.com. 2016. Diare, gejala, dan penyebab. [Online]. https://www.alodokter.com. Diakses 19 Juni 2018.

Anderson, E.T., \& McFarlane, J. 2011. Community As Partner. Theory and Nursing Practice. (6th ed). USA Lippincott Williams \& Williamas.

Depkes. 2006. Keputusan menteri kesehatan RI. No.279 Tahun 2016 Tentang Pedoman Penyelenggaraan Upaya Keperawatan Kesehatan Masyarakat di Puskesmas. [Online]. http://www.scrib.com

Dinas Kesehatan Kota Jayapura. (2013). Profil dinkes kota Jayapura, 2013). [Online]. www.depkes.go.id. Diunduh 23 Juni 2018.

Djuanda, S. 1993. Editor Djuanda., A, Djunada,S.,Hamzah, M., \& Aisah, S. Ilmu penyakit kulit dan kelamin. Edisi 2. Jakarta. Fakultas kedokteran Universitas Indonesia.

Edelman; \& Mandle. 2010. Health Promotion Throughout The Life Span. (7nt ed). Canada. Mosby Elsevier. Evolve learning system. ISBN:-978-0-323$05662-5$

Fajriani. 2016. Hubungan kepersediaan dan pemanfaatan sarana air bersih dan jamban dengan kejadian diare pada balita di wilayah kerja puskesmas Tunong kabupaten Aceh Timur. [Online]. Suwa.stikesbinusa.ac.id. Diunduh 18 Juni 2018 
Sumataera Uatara. [Online]. https://saripediatri.org. Diakses 19 Juni 2018.

Lundy, K.S.,and Janes, S. 2009. Community Health Nursing. Caring for The Public's Health. 2nd ed. Vo. 2. USA. Jones and Bartlett Publisher.

Maurer,FA., \& Smith, CM. 2005. Community Public Health Nursing. Helath for families \& Populatons. 3rd.Ed. Evolve. USA. Elsevier Saunders.

Nainggolan, O. 2009. Prevalendi dan faktor diterminan reumatik di Indonesia. Maj Kedokteran Indonesia. Vol 59. Nomor 12. Desember 2009. [Online]. https://kucrietzlophbatman.files.wordpre s.Diakses 19 Juni 2018.

Nies, M.A., \& McEwan, M. 2007. Community Health Nursing: Promoting The Health of Population. 3nd ed., Philadelphia: Davis Company.

Rachmawati, FA. 2012. Hubungan kepemilikan jamban dengan kejadian diare pada balita di Desa Jatisobo Kecamatan Polokarto Kabupaten Sukoharjao. Surakarta. Prodi Kesehatan Masyarakat Universitas Muhammadirah Surakarta. [Online].eprints.ums.ac.id. Diakses 18 Juni 2018.

Kemenkunham RI. 2005. Peraturan pemerintah Republik Indonesia. Nomor 73 tahun 2005. Tentang Kelurahan. [Onlien] www.jdih.kemekeu.go.id. Diakses 24 Juni 2018.

Kozier, AB., Erb's, SJN. 2012. Fundaental of Nursing. Concepts, Process and Praktice. Vol 1. 9th.ed. Berman E., \& Syder, S.USA. Pearson.

Kozier.G., \& Erb,G. '1979. Fundamental of Nursing. Cocept and Procedure. 2nd.ed. California. Addison Wesly Publissing Company.

Lubis, IND.,\& Lubis , CP. 2011. Penagangan demam pada anak. Departemen ilmu kesehatan anak, RS.H.Adam Malik. Medan Fakultas Kedokteran Universitas 
Skolnic, R. 2012. Global health. (Second Edition). Series editor: Riegelman, R. USA. Jones \& Bartlett Learning.

UHHS. 2011. Leading Health indicators healthly people 2020. [Online]. http://www.iom.edu/. Diakses 1 April 2013 Institute of medicine of the national academic.

Vovabulary. Com.? Health problem definition.[Onlin]. https://www.vocabulary.com > dictionary. Diakses 18 Juni 2018.

Witney.E., \& Rolfes, SD.2011. Understanding Nutrition.USA. Wardsworth Cengage Learning.www.cengage.com/wardwotrh.

World Health Organization (WHO). 2008. Infeksi Saluran pernafasan akut ISPA) yang cenderung menjadi epidemic dan pandemic. Pedoman ringkas. [Online ] www.who.int. Diakses 19 Juni 2018. 